\title{
Analysis construction industry on the basis of price trends of labor cost
}

\author{
Daniel Przywara ${ }^{1, *}$, and Adam Rak $^{2}$ \\ ${ }^{1}$ Msc, Eng, Opole University of Technology, Faculty of Civil Engineering and Architecture \\ ${ }^{2}$ Ph.D., D.Sc., Professor, Opole University of Technology, Faculty of Civil Engineering and \\ Architecture
}

\begin{abstract}
Records of the national, average pay rates in the construction industry, at quarterly intervals, allow cost - planning departments of contractors and investment services to assess current market conditions in the construction industry.

Price quarterly publications, such as Sekocenbud and Intercenbud, contain important information, enabling production preparation departments to prepare a comparison of the production in-house labor rates with the market production labor rates.

The article attempts to analyze the economic situation of domestic construction production in the years 2010-2016 based on the emerging price trends of the of labor cost estimates in this period, taking into account the impact of seasonal construction services.

In "Polish cost estimates standards", the labor cost estimate rate is present in one form: the net labor cost estimate rate, which fully corresponds to the rate defined in calculation formulas.

The rates of labor cost estimates, in individual regions of Poland, are shaped according to the presented market situations.

This clearly is reflected in the periodic (quarterly) regional records of labor rates in the Sekocenbud system.

The Act on prices of July 5, 2001 does not contain any normative regulations regarding the methods of cost estimation of construction works. The necessity to remain competitive forces large construction corporations to use a subcontracting system, involving several or even several dozen smaller, specialized in a narrow range of works, business entities in which labor costs are definitely lower, because they are reduced by a lower value of internal costs.
\end{abstract}

\section{Introduction}

Dynamic increases in labor cost estimate rates and material price increases that were noted at the end of 2006 and which continued practically until mid-2008 were manifested in a change in the structure of prices for construction works.

This phenomenon included labor costs, costs of materials and equipment work, which belong to direct costs in construction. It is characteristic that, from 2006 to 2009 in all groups of civil structures the share of labor costs in the price increased by several

\footnotetext{
* Corresponding author: d.przywara@po.opole.pl
} 
percent at the expense of the decreasing share of material and equipment costs (the absolute value of labor in this period increased by 96\%: from level PLN 8,05 per manhour to PLN 15.80 per manhour) [1].

Summing up, labor costs, fueled by several-year market prosperity, have become a significant value on the pages of cost estimates for companies operating in this sector [2]. The collapse of the global economic situation that took place at the turn of 2008-2009 has made significant changes in this respect - global market prosperity, ended with the economic crisis of the American banking, favored investments of all kinds that fueled the construction industry. Construction, being the driving force of the economy, had to go into stagnation in its "post-crisis" form.

The price-creating components that build the cost price of the works were defined in the study by the Central Construction Information Center in Warsaw [3], the production labor costs $(\mathrm{R})$ in the total costs of general construction works range from $12 \%$ to $20 \%$ [4] and constitute the second largest component. Methods for cost estimation of construction works [5] also specify the methods for calculating the hourly labor cost estimate [6-8].

\section{Analysis of price trends of labor cost estimate}

\subsection{Subject and methodology of research}

The analysis of price trends of labor cost estimate in the construction industry was divided into three research stages. Trends in the average net rate across the country (paragraph 2.2.) were analyzed in terms of general construction works: investment and renovation works as well as sanitary and electrical installation works. The study of national rate covered the period from the fourth quarter of 2009 to the first quarter of 2016, broken down into the aforementioned assortment of works. Construction market situation surveys in individual voivodships of the country (point 2.3.) were based on data from the first quarters of 2011, 2013 and 2015 - referring them to the average net rate for general construction works: investment works. The analysis of the labor price in construction, in the context of selected Polish cities (point 2.4.), was depicted on the basis of general construction works, based on data from the first quarter of 2016. The research was carried out on the basis of quarterly publications "Sekocenbud" of the Center for Economic and Organizational Construction Implementations (Ośrodek Wdrożeń Ekonomiczno-Organizacyjnych Budownictwa) "Promocja" sp. z o.o. in Warsaw [9].

\subsection{Average rate of labor cost estimate in the country}

Analysis of the average net rate in the country (Figure 1), in the fourth quarter of 2009, for general construction works: investment (14.24 PLN/h) and repairs (13.75 PLN/h) is a continuation of the ongoing stagnation on the construction services market. The average price for work, expressed in demand for services, fell in the second quarter of 2010: to14.17 PLN/h in investments and 13.67 PLN/h in repairs. From mid-2010 to the third quarter of 2011, there was a clear revival in the construction services - in this period, at three-month intervals, the discussed rates showed an upward trend - an average by 10 grosze in subsequent domestic records. 


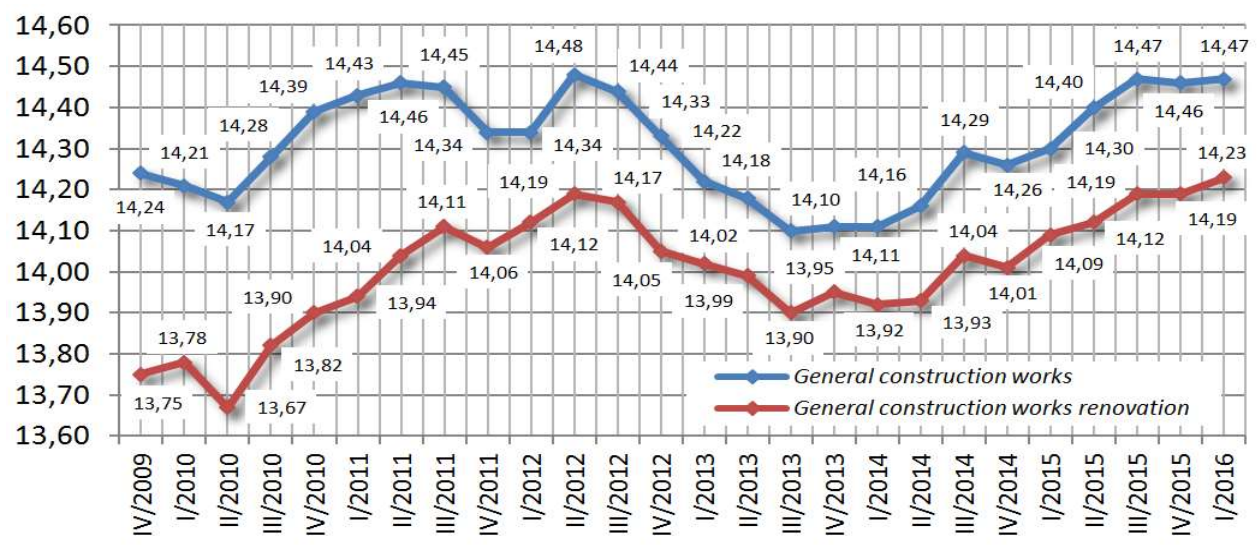

Fig. 1. Net operating rates [PLN/h] (mean values) for general construction: investment and repair during the IV quarter of $2009 \div$ I quarter 2016. Source: [9]

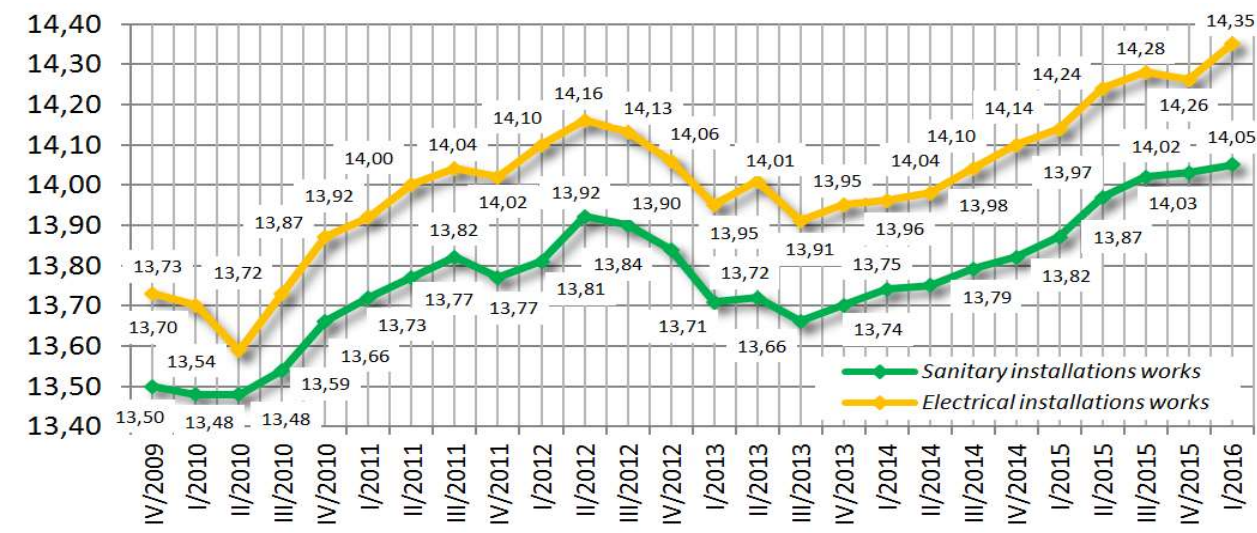

Fig. 2. Net operating rates $[\mathrm{PLN} / \mathrm{h}]$ (mean values) for installation works: sanitation and electricity during the IV quarter of $2009 \div$ I quarter 2016. Source: [9]

The turn of 2011/2012 brought another break, although not so significant. Raising from regression occurred faster in repair services (from the first quarter of 2012) than in investment works (second quarter of 2012).

In 2012, a gradual regression began, which lasted until spring of 2014. Net labor cost estimate rates fell: to the lowest of $14.11 \mathrm{PLN} / \mathrm{h}$ in investment works and $13.90 \mathrm{PLN} / \mathrm{h}$ in repair works. The slow process of "raising" rates, the trend of which is perceptible to the latest, analyzed trimester (I quarter of 2016), restored the price of production work to the level of the last breakdown, in the second quarter of 2012. A systematic, though slow, increase in prices for construction services raises optimistic predictions about future records.

On the market of installation services (Figure 2), trends of labor rates followed the situation of the price of construction occupations, traditionally adopting a lower value. The regressions of 2008-2010 and 2012-2014 were also marked here. The growing trend from the second period of collapse, however elevated the price of services in the installation industry to a higher ceiling against the "apogee" prices from mid-2012: up to $14.35 \mathrm{PLN} / \mathrm{h}$ in sanitary works and $14.05 \mathrm{PLN} / \mathrm{h}$ in electrical works. It is worth noting that, at turn of 2015/2016 for the first time over the years the prices for the electric services exceeded the value of $14.00 \mathrm{PLN} / \mathrm{h}$ net. Systematic increase in trends, since the beginning of 2014, in the analyzed assortments of works, allows to make optimistic prognosis. 


\subsection{Average rate of labor cost estimate in the voivodships}

In general construction investment works (in the first quarters of 2011, 2013 and 2015: Figure No. 3), the Sekocenbud publishings, in sixteen voivodship centers, systematically regress in eight voivodships: Lower Silesian, Kuyavian-Pomeranian, Lubusz, Łódź, Masovian, Pomeranian, Silesian and West Pomeranian.

The highest rate of decline in the net hour rate is in the Lower Silesian Voivodship: the reduction of the labor price at the construction of new facilities amounted to as much as $1.47 \mathrm{PLN} / \mathrm{h}$ (from 14.52 PLN/h to $13.05 \mathrm{PLN} / \mathrm{h}$ ), for the voivodship in general. The Pomeranian Voivodship is in second place, in which the reduction of the man-hour rate by $1.00 \mathrm{PLN} / \mathrm{h}$ net was recorded (from $15.88 \mathrm{PLN} / \mathrm{h}$ to $14.88 \mathrm{PLN} / \mathrm{h}$ ). In other centers, the reduction ranges from PLN 0.10 to 0.65 . Non-systematic economic fluctuations, expressed in the labor price, the trends "in plus" and "in minus" changing in two-year research periods, occur in seven voivodships: Lublin, Lesser Poland, Opole, Podkarpackie, Podlasie, Świętokrzyskie and Warmian-Masurian.

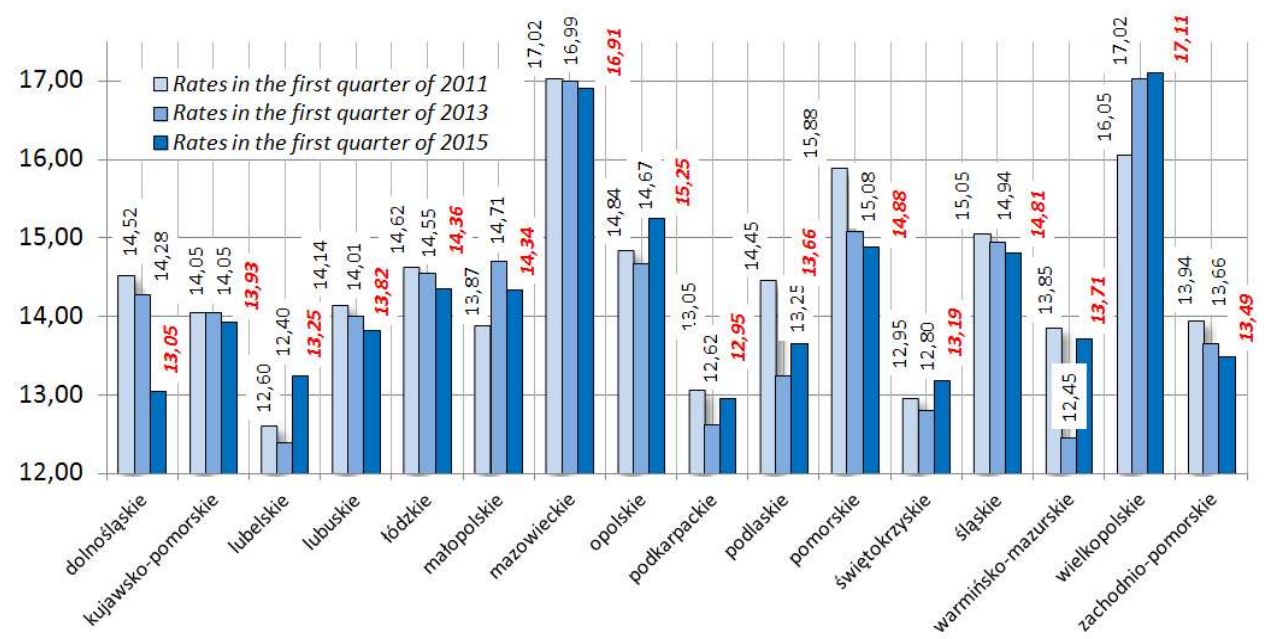

Fig. 3. Net operating rates $[\mathrm{PLN} / \mathrm{h}]$ (mean values) for general construction investment in the first quarter of the year 2011/2013/2015. Source: [9]

These trends have different monotonicity -in six cases year 2013 brought the lowest records of the studied rate, in one center (Lesser Poland) the analysis showed the highest price for work in this period $(14.71 \mathrm{PLN} / \mathrm{h})$. The exception is the Greater Poland Voivodeship, where the rate has been steadily increasing.

Comparison of the economic situation at the level of sixteen voivodships, in the context of general investment construction works - in the four-year period of analysis, allows a more accurate assessment of the country's economic situation in its individual administrative centers, because it illustrates trends in their economic situation, difficult transition period in the construction industry in 2011-2013 (Figure 1), although significant, two-year jumps in this analysis give only a general outline of the phenomena described, they also allow to eliminate the seasonal factor, so characteristic for this branch of the economy.

\subsection{Average rate of labor cost estimate in selected cities}


The analysis of the net cost-estimate manhour rate - in the capitals of voivodships, in the first quarter of 2016 (according to Sekocenbud) is shown in Figure 4.

Next to the names of voivodships centers, their place in the analyzed ranking was given. The difference in the extreme values of production labor rate $(18.50 \mathrm{PLN} / \mathrm{h}$ for Warsaw and $13.40 \mathrm{PLN} / \mathrm{h}$ in Wroclaw), amounting to $38.06 \%$ in the current period, reflects the economic prosperity of the country's capital, expressed in employee demand.

Poznań is in second place (17.00 PLN/h), then -with a rate above 15.30 PLN/h- Katowice, Opole and Gdańsk. The price per hour of work in general investment construction works in the amount of $15.00 \mathrm{PLN} / \mathrm{h}$ was recorded in Kraków and Lódź, rate in the amount of 14.00 PLN/h is in Szczecin, Zielona Góra, Rzeszów, Lublin, Białystok and Kielce. Below this amount, in the current quarter we have Bydgoszcz (13.90 PLN/h), Olsztyn (13.50 PLN/h) and Wroclaw (13.40 PLN/h).

In order to estimate the economic situation of Polish voivodships, the analysis should be referred also to poviat cities, forming together with them, urban agglomerations.

Figure 5 lists the man-hour rates of sixteen urban agglomerations, giving a place in the national ranking next to the name of the agglomeration (the order presented in Figure 4 was kept). The Mazovian agglomeration with its $9^{\text {th }}$ place is an unusual case in this histogram, behind such urban groups as the Silesian, Opole, Pomeranian, Lesser Poland, Łódź, Lubusz or Podlasie agglomerations. This shows a significant stratification of the economic situation in construction production in total in the capital voivodship, whose poviat centers lower the average net rate for work on the construction site by a total value of PLN 5,11. The highest result is recorded in the Greater Poland agglomeration - with Poznan as the leader, whose neighboring centers reduce its value of construction work by only ten grosze. The Opole region ranks in the second place in the ranking of urban agglomerations: here, the differences in the economic situation of the capital, referred to the total voivodship, amount to $0.72 \mathrm{PLN} / \mathrm{h}$.

Comparing this voivodship center to the neighboring Lower Silesian agglomeration, there is also an upward trend of Wrocław, rated together with poviat cities: the drop in the value of the rate was only 13 grosze, while Lower Silesia, out of the last ranking place of the voivodship capitals overtook, in the ranking of urban teams, Lublin and West Pomeranian. Comparison of figures 4 and 5 illustrates the general tendency: in all voivodships, capitals play the role of dominant, with the greatest demand for construction services, although there are local exceptions.

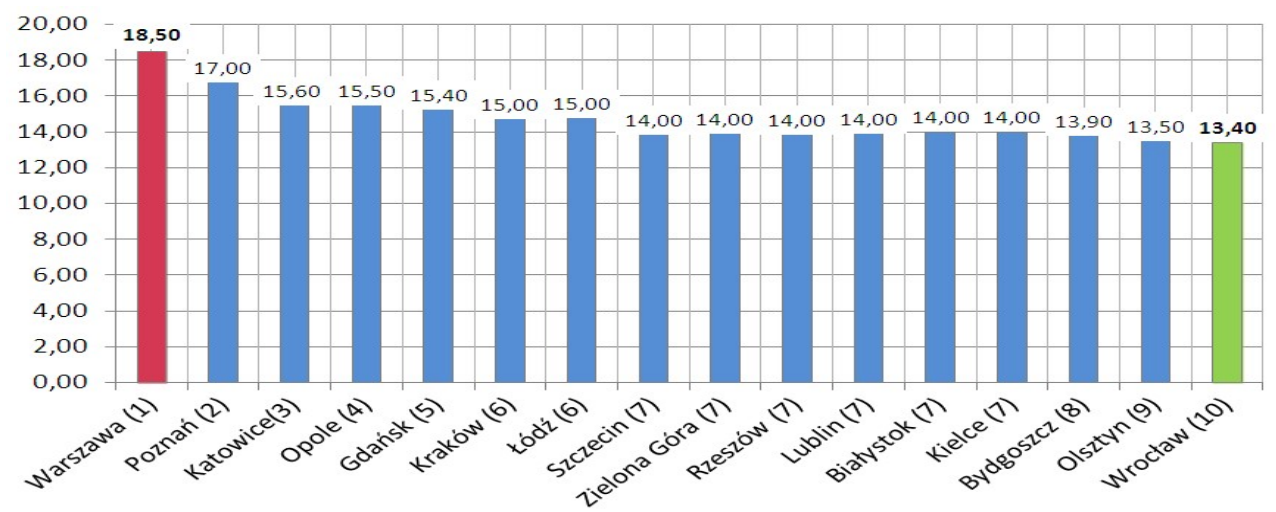

Fig. 4. Average rate of net operating $[\mathrm{PLN} / \mathrm{h}]$ in the capital of provinces for Works general construction in the first quarter of 2016 years. Source: [9] 


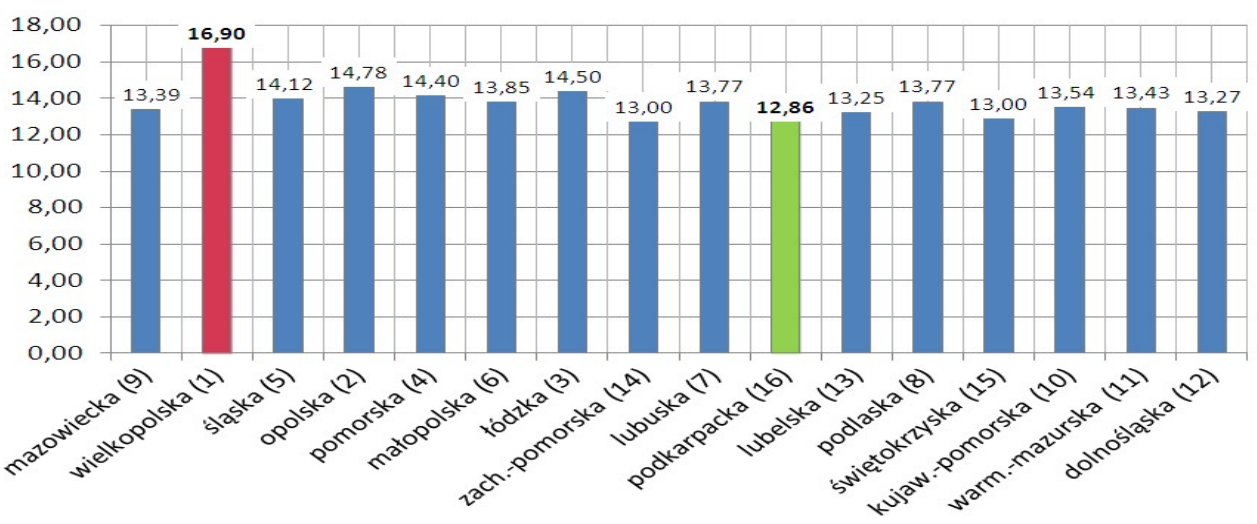

Fig. 5. Average rate of net operating $[\mathrm{PLN} / \mathrm{h}]$ in Urban areas for work general construction in the first quarter of 2016 years. Source: [9]

\section{Conclusions from research and analysis}

Specificity of the implementation of construction projects characterized with seasonality causes the necessity of analyzing the occurring price trends in the distribution both at the time and place of occurrence. Prepared analyzes of labor rates: on the national scale, in voivodships and in selected cities, suggest the spectrum of conclusions.

The salary pricing trends after the regression period from 2011-2013 have been increasing continuously since the beginning of 2014. Estimate labor rates at the level of voivodships, in the last four years, show fast growth trends in construction works - with their assessment in base 2015. Analysis of the labor price in the capitals of individual voivodships, in which the first quarter of 2016 was adopted as the reference point, gives a blurry picture of the situation on the market of construction services in voivodships treated as one economic organism. A list of price trends in selected regions of the country indicates strong industrial centers, forming urban agglomerations with an economic situation exceeding the capital region, as well as centers that form economic centers, drawing from neighboring poviat cities, which are their staff resources.

\section{References}

1. Niemczyk R., Price structure for construction works (research by Orgbud-Serwis, Inżynier Budownictwa, No. 9(65), 2009, p. 38-40)

2. Przywara D., Outsourcing of construction works and auxiliary production in the production branch of the enterprise (MA thesis, Faculty of Economics at the Opole University in Opole, Opole 2010)

3. Rajczyk M., Cost estimation of construction works ( $2^{\text {nd }}$ edition), 185 (2009)

4. Kacprzyk B., Cost estimation of buildings and construction works (published by Polcen sp. z o.o., Warsaw 2010)

5. Plebankiewicz E., Fundamentals of cost estimation of construction works - didactic help, 64-96 (Cracow 2007)

6. Sikorska-Ożgo W., Detailed calculation in the cost estimation of construction works $\left(5^{\text {th }}\right.$ edition) (published by O.W.E.O.B. „Promocja” sp. z o.o., Warsaw 2009) 
7. Lapierre $Ł .$, Cost estimate in contracts for construction works ( $5^{\text {th }}$ edition) (published by O.W.E.O.B. „Promocja” sp. z o.o., Warsaw 2009)

8. Przywara D., Rak A., Outsourcing of construction works as a way to solve high internal costs in a construction company (Przegląd Budowlany, p. 43-48, January 2016)

9. Sikorska-Ożgo W., Information on labor cost estimate rates and construction equipment prices (published by O.W.E.O.B. „Promocja” sp. z o.o., Warsaw: data from $2009 \div 2016$ (quarterly information) 